\title{
Effect of source of trace minerals in either forage- or by-product-based diets fed to dairy cows: 1. Production and macronutrient digestibility
}

\author{
M. J. Faulkner ${ }^{1}$ and W. P. Weiss ${ }^{2}$ \\ Department of Animal Sciences, Ohio Agricultural Research and Development Center, The Ohio State University, Wooster 44691
}

\begin{abstract}
Excess rumen-soluble $\mathrm{Cu}$ and $\mathrm{Zn}$ can alter rumen microbial populations and reduce fiber digestibility. Because of differences in particle size and chemical composition, ruminal and total-tract digestibility of fiber from forage- and by-product-based diets can differ. We hypothesized that, because of differences in mineral solubility, diets with hydroxy rather than sulfate trace minerals would have greater fiber digestibility, but the effect may depend on source of fiber. Eighteen multiparous cows were used in a split-plot replicated Latin square with two 28-d periods to evaluate the effects of $\mathrm{Cu}, \mathrm{Zn}$, and $\mathrm{Mn}$ source (sulfates or hydroxy; Micronutrients USA LLC, Indianapolis, IN) and neutral detergent fiber (NDF) source (forage diet $=26 \% \mathrm{NDF}$ vs. by-product $=36 \%$ ) on total-tract nutrient digestibility. During the entire experiment $(56 \mathrm{~d})$ cows remained on the same fiber treatment, but source of supplemental trace mineral was different for each 28 -d period so that all cows were exposed to both mineral treatments. During each of the two 28-d periods, cows were fed no supplemental $\mathrm{Cu}, \mathrm{Zn}$, or $\mathrm{Mn}$ for $16 \mathrm{~d}$ followed by $12 \mathrm{~d}$ of feeding supplemental $\mathrm{Cu}, \mathrm{Zn}$, and $\mathrm{Mn}$ from either sulfates or hydroxy sources. Supplemental minerals for each of the mineral sources fed provided approximately 10,35 , and $32 \mathrm{mg} / \mathrm{kg}$ of supplemental $\mathrm{Cu}, \mathrm{Zn}$, and $\mathrm{Mn}$, respectively, for both fiber treatments. Total dietary concentrations of $\mathrm{Cu}, \mathrm{Zn}$, and $\mathrm{Mn}$ were approximately 19,65 , and $70 \mathrm{mg} / \mathrm{kg}$ for the forage diets and 21,85 , and $79 \mathrm{mg} / \mathrm{kg}$ for the by-product diets, respectively. Treatment had no effect on dry matter intake $(24.2$ $\mathrm{kg} / \mathrm{d})$ or milk production $(34.9 \mathrm{~kg} / \mathrm{d})$. Milk fatty acid profiles were altered by fiber source, mineral source, and their interaction. Cows fed the by-product diets had lower dry matter ( 65.9 vs. $70.2 \%$ ), organic matter (67.4 vs. $71.7 \%$ ), and crude protein digestibility (58.8
\end{abstract}

Received October 3, 2016.

Accepted March 4, 2017.

${ }^{1}$ Current address: VitaPlus, Madison, WI 53713.

${ }^{2}$ Corresponding author: weiss.6@osu.edu vs. $62.1 \%$ ) but greater starch (97.5 vs. $96.3 \%)$ and NDF digestibility ( 50.5 vs. $44.4 \%$ ) compared with cows fed the forage treatment. Feeding increased concentrations of by-products decreased total digestible nutrients regardless of mineral source. Feeding hydroxy $\mathrm{Cu}, \mathrm{Zn}$, and Mn increased NDF digestibility (48.5 vs. 46.4\%) but had no effect on total digestible nutrients.

Key words: trace mineral, fiber, digestibility

\section{INTRODUCTION}

Source and amounts of trace minerals can affect ruminal fermentation. Organic trace minerals $(\mathrm{Cu}, \mathrm{Zn}$, $\mathrm{Mn}, \mathrm{Se}$, and Co) had no effect on nutrient digestibility by dairy heifers but increased total VFA production compared with sulfate minerals (Pino and Heinrichs, 2016). Excessive in vitro $\mathrm{Cu}$ (Durand and Kawashima, 1980) and Zn (Arelovich et al., 2000; Eryavuz and Dehority, 2009) supplementation negatively affects microbial populations and rumen fermentation. Ruminal solubility of trace minerals is likely a factor that influences how trace minerals affect rumen fermentation and microbial populations, which may in turn affect nutrient digestibility. Hydroxy $\mathrm{Cu}$ and $\mathrm{Mn}$ are less soluble in the rumen compared with sulfate sources, whereas differences in solubility of hydroxy Zn and Zn sulfate are inconsistent (Cao et al., 2000; Genther and Hansen, 2015). Reducing the concentration of soluble trace minerals, particularly $\mathrm{Cu}$, by feeding hydroxy minerals may increase ruminal digestibility.

Substitution of forage fiber with nonforage fiber sources (i.e., by-products) in dairy rations is a common field practice; however, the source and physical characteristics of dietary fiber affects ruminal fermentation and extent and site of nutrient digestibility (Allen and Mertens, 1988; Firkins, 1997; Varga and Kolver, 1997). By-product-based diets often have less starch than forage-based diets, and starch can inhibit fiber digestibility (Ferraretto et al., 2013). Because of the numerous differences between forage- and by-product-based diets, trace mineral source (i.e., solubility) may affect diets differently depending on carbohydrate sources and concentrations. 
Table 1. Ingredient composition of the $\operatorname{diet}^{1}(\%$ of DM)

\begin{tabular}{|c|c|c|c|c|}
\hline \multirow[b]{2}{*}{ Ingredient } & \multicolumn{2}{|c|}{ Forage } & \multicolumn{2}{|c|}{ By-product } \\
\hline & Sulfate & Hydroxy & Sulfate & Hydroxy \\
\hline Corn silage & 44.0 & 44.0 & 20.0 & 20.0 \\
\hline Alfalfa silage & 20.0 & 20.0 & 15.0 & 15.0 \\
\hline Ground corn & 18.5 & 18.5 & - & - \\
\hline Soybean meal, $48 \% \mathrm{CP}$ & 14.9 & 14.9 & 8.5 & 8.5 \\
\hline Rolled oats & - & - & 14.1 & 14.6 \\
\hline Dried corn gluten feed & - & - & 11.0 & 11.0 \\
\hline Dried beet pulp & - & - & 15.0 & 15.0 \\
\hline Soy hulls & - & - & 14.1 & 14.1 \\
\hline Animal/vegetable fat & 0.51 & 0.51 & 0.65 & 0.65 \\
\hline Limestone & 0.69 & 0.69 & 0.47 & 0.47 \\
\hline Magnesium oxide & 0.16 & 0.16 & 0.07 & 0.07 \\
\hline Dicalcium phosphate & 0.25 & 0.25 & 0.13 & 0.13 \\
\hline Iodized salt & 0.48 & 0.48 & 0.42 & 0.42 \\
\hline Selenium premix ${ }^{2}$ & 0.15 & 0.15 & 0.15 & 0.15 \\
\hline Vitamin $\operatorname{mix}^{3}$ & 0.37 & 0.37 & 0.37 & 0.37 \\
\hline $\mathrm{Cu}$ sulfate & 0.0003 & - & 0.0003 & — \\
\hline Zn sulfate & 0.0008 & - & 0.0008 & - \\
\hline Mn sulfate & 0.0008 & - & 0.0008 & - \\
\hline Hydroxy $\mathrm{Cu}^{4}$ & - & 0.0001 & - & 0.0001 \\
\hline Hydroxy Zn & - & 0.0005 & - & 0.0005 \\
\hline Hydroxy Mn & - & 0.0006 & - & 0.0006 \\
\hline \multicolumn{5}{|c|}{$\begin{array}{l}{ }^{1} \text { Forage- or by-product-based diets with } \mathrm{Cu}, \mathrm{Zn} \text {, and } \mathrm{Mn} \text { from sulfate or hydroxy mineral sources. } \\
{ }^{2} \text { Sodium selenate, } 200 \mathrm{mg} / \mathrm{kg} \text {. }\end{array}$} \\
\hline \multicolumn{5}{|c|}{$\begin{array}{l}{ }^{3} \text { Contained } 735 \mathrm{kIU} \text { of vitamin A/kg, } 270 \mathrm{kIU} \text { of vitamin D } / \mathrm{kg}, 4,400 \mathrm{IU} \text { of vitamin } \mathrm{E} / \mathrm{kg} \text {, and } 135 \mathrm{mg} \text { of biotin } \\
\text { (Rovimix Biotin, DSM Nutritional Products, Heerleen, the Netherlands) } / \mathrm{kg} \text {. } \\
{ }^{4} \text { IntelliBond C, Z, M (IntelliBond; Micronutrients USA LLC, Indianapolis, IN). Based on assays, the products } \\
\text { contained approximately 59, 57, and } 45 \% \mathrm{Cu} \text {, Zn, and Mn, respectively. }\end{array}$} \\
\hline
\end{tabular}

Few published data exist detailing the interaction of dietary mineral and fiber sources on nutrient digestibility in ruminants. We hypothesized that because of differences in rumen solubility, source of trace mineral would affect fiber digestibility (i.e., sulfate source would negatively affect digestibility) and the difference would be greater for diets with greater concentrations of fiber (e.g., by-product-based diets). Furthermore, because milk fatty acid (FA) profile can change in response to changes in ruminal fermentation, treatments and interactions could also affect milk FA profile. The objectives of our study were to investigate the effects of trace mineral source on nutrient digestibility and subsequent changes in milk FA composition when fed in forage- or by-product-based diets.

\section{MATERIALS AND METHODS}

\section{Cows and Treatments}

All animal procedures were approved by The Ohio State University Institutional Animal Care and Use Committee. Eighteen multiparous Holstein cows were placed into 3 groups of 6 cows based on DIM (153 \pm 36 DIM at the start of the experiment) and used in a splitplot experiment. Within each group, 3 cows were ran- domly assigned to 1 of 2 fiber treatments (whole-plot treatment) and remained on that treatment throughout the entire experiment. Whole-plot diets were based on forage or by-product fiber sources (Tables 1 and 2 ). The split-plot treatments (source of supplemental mineral) were arranged as a $2 \times 2$ Latin square $(2$ cows and 2 periods per square). Groups were limited to 6 cows because only 6 digestion stalls were available at our facility. Within a group and period, treatment replications were not balanced (i.e., within each period, 2 treatments were fed to 2 cows each and 2 treatments were applied to only 1 cow each); however, over the entire experiment, replication was balanced.

Following NRC (2001) guidelines, the by-product diets were formulated to have greater concentrations of total NDF and lesser concentrations of starch compared with the forage-based diets. In addition by-products were chosen to specifically increase concentrations of $\beta$-glucans, and neutral detergent-soluble fiber because these may bind minerals. Within the whole-plot treatment, each cow was assigned to 1 of 2 supplemental mineral treatment (split-plot treatment) sequences. The experiment had two 28-d periods that consisted of a 16-d phase when no supplemental $\mathrm{Cu}, \mathrm{Zn}$, or $\mathrm{Mn}$ were fed followed by a 12-d phase of feeding supplemental minerals as sulfates or hydroxy forms (IntelliBond C, 
Table 2. Analyzed nutrient composition of diets and ingredients without supplemental $\mathrm{Cu}, \mathrm{Zn}$, and Mn (DM basis)

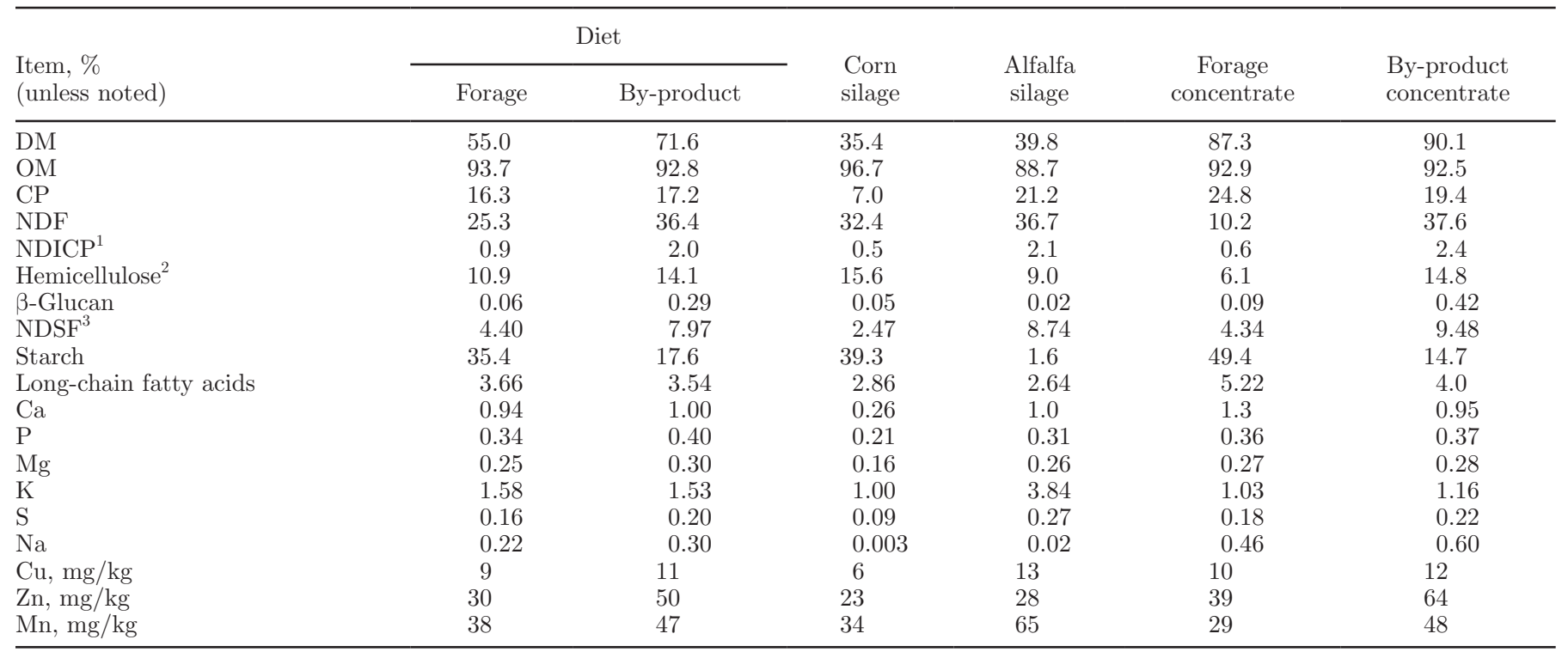

${ }^{1} \mathrm{NDICP}=$ neutral detergent insoluble $\mathrm{CP}$

${ }^{2}$ Hemicellulose $=\mathrm{NDF}-\mathrm{ADF}$.

${ }^{3} \mathrm{NDSF}=$ neutral detergent-soluble fiber by difference (Hall et al., 1999).

Z, and M; Micronutrients USA LLC., Indianapolis, IN). As expected, fiber treatments differed in basal trace mineral concentration (Table 2). To test the hypothesis that source, not amount, of supplemental trace mineral affected digestibility, supplemental trace minerals were fed in a top dress $(0.2 \mathrm{~kg} / \mathrm{d})$ so that the concentration of supplemental trace mineral fed was held constant across fiber treatments (Table 3). Therefore, the proportion of total $\mathrm{Cu}, \mathrm{Mn}$, and $\mathrm{Zn}$ provided by basal and supplemental sources varied between fiber treatments
(Table 3). Mineral concentrations were chosen to be similar to on-farm supplementation rates.

Cows were housed in individual tiestalls and fed once daily with a target refusal rate of $5 \%$ delivered feed. Cows were milked $2 \times / \mathrm{d}$ at approximately 0200 and $1400 \mathrm{~h}$ (milk yields for each cow were measured electronically). Individual feed delivery and refusal amounts were weighed and recorded daily. Cows were weighed on 2 consecutive mornings (approximately $4 \mathrm{~h}$ after feeding) at the beginning (used for period $1 \mathrm{BW}$ )

Table 3. Concentrations of supplemental and total dietary $\mathrm{Cu}, \mathrm{Zn}$, and $\mathrm{Mn}(\mathrm{mg} / \mathrm{kg}$ diet $\mathrm{DM})$

\begin{tabular}{|c|c|c|c|c|}
\hline \multirow[b]{3}{*}{ Item } & \multicolumn{4}{|c|}{ Treatment $^{1}$} \\
\hline & \multicolumn{2}{|c|}{ Forage } & \multicolumn{2}{|c|}{ By-product } \\
\hline & Sulfate & Hydroxy & Sulfate & Hydroxy \\
\hline \multicolumn{5}{|c|}{ Supplemental minerals concentrations ${ }^{2}$} \\
\hline $\mathrm{Cu}$ & 10 & 9 & 11 & 9 \\
\hline $\mathrm{Zn}$ & 34 & 37 & 36 & 34 \\
\hline $\mathrm{Mn}$ & 33 & 32 & 34 & 31 \\
\hline \multicolumn{5}{|c|}{ Total dietary concentrations } \\
\hline $\mathrm{Cu}$ & 19 & 18 & 22 & 20 \\
\hline $\mathrm{Zn}$ & 64 & 67 & 86 & 84 \\
\hline $\mathrm{Mn}$ & 71 & 70 & 81 & 78 \\
\hline \multicolumn{5}{|c|}{ Supplemental mineral, $\%$ of total dietary mineral } \\
\hline $\mathrm{Cu}$ & 53 & 50 & 50 & 45 \\
\hline $\mathrm{Zn}$ & 53 & 55 & 42 & 41 \\
\hline $\mathrm{Mn}$ & 46 & 46 & 42 & 40 \\
\hline
\end{tabular}

${ }^{1}$ Forage- or by-product-based diets with $\mathrm{Cu}, \mathrm{Zn}$, and $\mathrm{Mn}$ from sulfate or hydroxy mineral sources.

${ }^{2}$ Concentrations based on treatment average DMI. 
and end of the experiment (used for period 2 BW). Body condition score was evaluated at the beginning and end of each period by 2 trained technicians working independently.

\section{Digestion Collection and Feed Samples}

On d 24 of each period (d 8 of feeding supplemental minerals), cows were moved to specifically designed stalls within the same barn and total output of urine and feces was measured daily, sampled, and composited within cow over the for 4-d collection period (Weiss et al., 2009). Water intake was measured and recorded daily during the digestion collection by water meters connected to each individual water bowl. Milk and wet fecal samples were analyzed for N (AOAC International, 2000; 984.13.4.09) within a few hours of the conclusion of each collection period. Urine samples were frozen and analyzed for N (AOAC International, 2000; 984.13.4.09) at a later date.

During the collection period, silages, concentrates, and orts for each cow were sampled daily and composited into a 4-d sample (Weiss et al., 2009). Silage, fecal, and refusal samples were frozen, lyophilized, and ground through a 1-mm screen (Wiley mill; Arthur H. Thomas Co., Philadelphia, PA). Concentrates were ground but not dried. Dried ground samples of feeds, feces, and refusals were assayed for DM $\left(100^{\circ} \mathrm{C}\right.$ for $\left.24 \mathrm{~h}\right)$, ash $\left(600^{\circ} \mathrm{C}\right.$ overnight), N (AOAC International, 2000; 984.13.4.09), starch (Weiss and Wyatt, 2000), longchain fatty acids (LCFA; Weiss and Wyatt, 2003), and NDF $\left(\right.$ Ankom ${ }^{200}$ Fiber Analyzer; Ankom Technology Corp., Fairport, NY) with sodium sulfite and amylase (Sigma Diagnostics, St. Louis, MO). Feed samples were assayed for mixed-linkage $\beta$-glucans, neutral detergentsoluble fiber (Hall et al., 1999), ADF (AOAC International, 2000), and neutral detergent insoluble N. Feed, orts, and fecal samples were sent in blind duplicates to Cumberland Valley Analytical Services (Hagerstown, MD) for mineral analyses using standard wet chemistry methods (AOAC International, 2000; CVAS, 2014). Mineral samples were ashed $\left(1 \mathrm{~h}\right.$ at $\left.535^{\circ} \mathrm{C}\right)$, digested in $15 \%$ nitric acid, diluted, and assayed by inductively coupled plasma emission spectroscopy.

\section{Milk Samples}

Weekly milk samples (a.m. and p.m.) were collected and analyzed for milk fat, protein, lactose (B2000 Infrared Analyzer, Bentley Instruments, Chaska MN), and MUN (Skalar SAN Plus segmented flow analyzer, Skalar Inc., Norcross, GA) by DHI Cooperative Inc.
(Columbus, OH). Additional p.m. milk samples were collected on d 16 following the removal of supplemental $\mathrm{Cu}, \mathrm{Zn}$, and $\mathrm{Mn}$ and $\mathrm{d} 12$ following the feeding of supplemental $\mathrm{Cu}, \mathrm{Zn}$, and $\mathrm{Mn}$ for each period and analyzed for milk FA profile. The milk fat layer was removed and the milk FA profile was determined using a 2-step procedure for methylation (Jenkins, 2000) with separation by gas-liquid chromatography using a CPSIL88 capillary column $(100 \mathrm{~m} \times 0.25 \mathrm{~mm} \times 0.2-\mu \mathrm{m}$ film thickness; Varian Inc., Palo Alto, CA).

\section{Calculations and Statistical Analyses}

One cow was removed from the experiment after period 1 because of a physical injury; all data for this cow from period 2 were excluded in data analysis. Apparent digestibility and balance of nutrients were calculated for each cow-period. Concentration of NFC was calculated as

$$
\begin{gathered}
100-(\mathrm{NDF}-\text { neutral detergent insoluble CP }) \\
-\mathrm{CP}-\mathrm{LCFA}-\mathrm{Ash},
\end{gathered}
$$

where all values are expressed as percentage of DM. Concentration of TDN was calculated by summing the products of the appropriate apparent digestibility coefficients times the concentration of NDF, CP, NFC, and $(\mathrm{LCFA} \times 2.25)$. Production data collected during the last $7 \mathrm{~d}$ of each period (a time when supplemental minerals were fed) was averaged and analyzed statistically. All data were analyzed using PROC MIXED (v9.3; SAS Institute Inc., Cary, NC) using a model that included the fixed effects of fiber (1 df), mineral source $(1 \mathrm{df})$, their interaction $(1 \mathrm{df})$, the random effects of group (2 df), group $\times$ fiber $(2 \mathrm{df})$, period $(1 \mathrm{df})$, period $\times$ group $(3 \mathrm{df})$, cow within group $\times$ fiber, and residual error.

\section{RESULTS AND DISCUSSION}

\section{Production Measures}

Cows fed forage-based diets (i.e., less NDF and greater starch concentrations) had greater MUN $(P$ $<0.01)$ and milk fat concentrations and yields $(P<$ 0.03) compared with cows fed by-product diets, but no other production measure was affected by treatment (Table 4). The forage-based diets likely stimulated chewing to a greater extent than the low-forage byproduct diets (Krause and Combs, 2003) and increased milk fat production. Different from results observed in this experiment, increasing dietary starch typically 
decreases MUN (Valadares Filho et al., 2000; Weiss et al., 2009; Ferraretto et al., 2013); however, short-term and abrupt increases in dietary starch can increase MUN (Gott et al., 2015). Diets differed substantially in source of protein, and differences in protein fractions and AA may have caused differences in MUN.

\section{Water Intake}

During the 4-d collection period, DMI did not differ among treatments (Table 5). Urine output was greater $(P<0.03)$ for cows fed the forage diets compared with the by-product diets ( 22.4 vs. $18.9 \mathrm{~kg} / \mathrm{d})$ even though total water intake was not statistically different (Table $5)$. Cows fed the forage diets had greater intakes of dietary water $(P<0.01)$, but free and total water intake were similar $(P \geq 0.38)$ between fiber treatments. This paradox was likely caused by greater variation among cows in free water intake compared with diet water. Interestingly, free water intake was greater $(P$ $=0.07)$ and total water intake tended to be greater $(P$ $=0.10$ ) for cows consuming sulfate minerals compared with hydroxy minerals. The reason for increased water intake is unclear, but the difference in $\mathrm{S}$ concentrations between mineral treatments was probably too small to affect water intake. Direct data from other studies that corroborate a trace mineral source effect on water intake are lacking; however, based on wet fecal and urine output, increased water intake for dairy heifers consuming sulfate minerals compared with organic trace minerals may have occurred in another study (Pino and Heinrichs, 2016). Additional studies are needed to verify these results.

\section{Apparent Nutrient Digestibility}

Apparent absorption of minerals is discussed in the companion paper (Faulkner et al., 2017). No fiber by mineral interactions were observed for apparent digestibility of any nutrient $(P>0.34)$. Digestibility of NDF and starch were greater $(P<0.01)$ and LCFA digestibility tended to be greater $(P<0.09)$ by cows fed the by-product diets; however, concentrations of TDN were less $(P<0.01)$ for cows fed the by-product diets (Table $5)$. The greater apparent digestibility of LCFA in the by-product diets could have been caused by different FA profiles (Table 6) and by inherent differences in digestibility of LCFA contained in forages compared with concentrates. Loor et al. (2004) reported a similar difference between a forage-based and a by-productbased diet.

Apparent starch and NDF digestibilities were less for forage diets compared with by-product diets (Table 5). Essentially all the starch in the forage diets was from corn, but oats provided about $50 \%$ of the starch in the by-product diets and oat starch may be more digestible than corn starch (Herrera-Saldana et al., 1990). The greater NDF digestibility for the by-product diets could be caused by inherent differences in the digestibility of the fiber sources (Bhatti and Firkins, 1995) or because of negative associative effects caused by the high concentration of starch in the forage diets (Firkins, 1997; Ferraretto et al., 2013). The negative effect of starch on fiber digestibility, however, is often associated with reduced milk fat (Sutton et al., 1987; Ferraretto et al., 2013), and in our experiment cows fed the forage diets had lesser NDF digestibility but greater milk fat yield.

Table 4. Production responses during last $7 \mathrm{~d}$ of the supplemental mineral period

\begin{tabular}{|c|c|c|c|c|c|c|c|}
\hline \multirow[b]{2}{*}{ Response variable } & \multicolumn{4}{|c|}{ Treatment $^{1}$} & \multirow[b]{2}{*}{$\mathrm{SEM}^{2}$} & \multicolumn{2}{|c|}{$P<<^{3}$} \\
\hline & Sulfate & Hydroxy & Sulfate & Hydroxy & & Fiber & Mineral \\
\hline DMI, kg & 24.5 & 24.3 & 23.9 & 24.0 & 1.4 & 0.76 & 0.96 \\
\hline $\mathrm{BW}, \mathrm{kg}$ & 640 & 643 & 608 & 605 & 22.0 & 0.26 & 1.00 \\
\hline $\mathrm{BCS}$ & 3.0 & 3.0 & 3.0 & 3.0 & 0.2 & 0.84 & 0.43 \\
\hline Milk fat, kg/d & 1.42 & 1.45 & 1.19 & 1.13 & 0.13 & 0.03 & 0.86 \\
\hline Milk protein, \% & 2.98 & 3.10 & 2.96 & 2.92 & 0.1 & 0.44 & 0.59 \\
\hline Milk protein, $\mathrm{kg} / \mathrm{d}$ & 1.03 & 1.09 & 1.00 & 0.98 & 0.07 & 0.27 & 0.60 \\
\hline MUN, mg/dL & 15.4 & 15.4 & 11.4 & 11.5 & 1.0 & 0.01 & 0.98 \\
\hline
\end{tabular}

${ }^{1}$ Forage- or by-product-based diets with $\mathrm{Cu}, \mathrm{Zn}$, and $\mathrm{Mn}$ from sulfate or hydroxy mineral sources.

${ }^{2}$ Data were unbalanced due to one missing observation; therefore, the greatest SEM values were reported.

${ }^{3}$ No fiber $\times$ mineral interactions were observed $(P>0.26)$. 
Table 5. Effects of feeding different fiber and trace mineral sources on digestibility and water intake

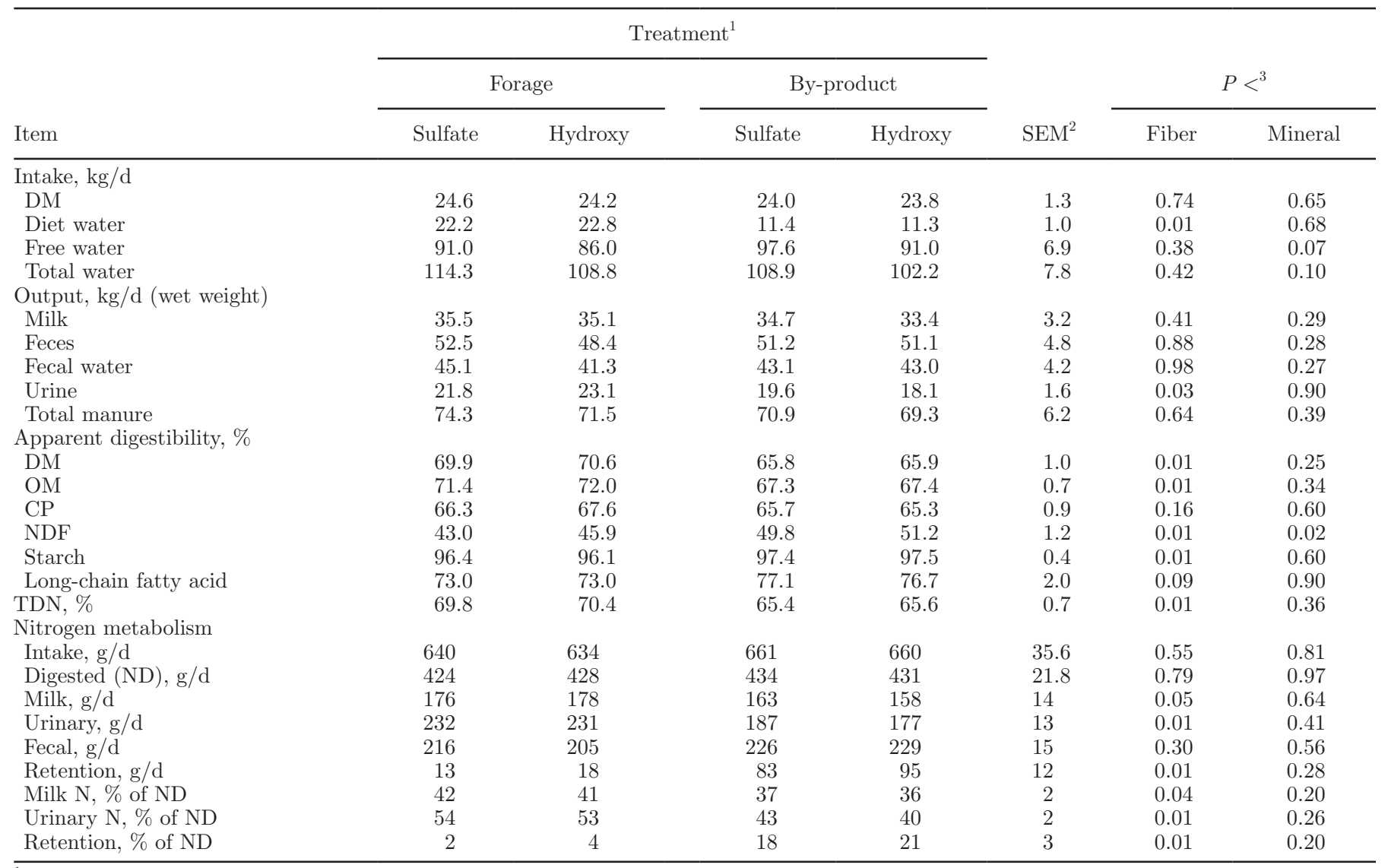

${ }^{1}$ Forage- or by-product-based diets with $\mathrm{Cu}, \mathrm{Zn}$, and $\mathrm{Mn}$ from sulfate or hydroxy mineral sources.

${ }^{2}$ Data were unbalanced due to one missing observation; therefore, the greatest SEM values were reported.

${ }^{3}$ No fiber $\times$ mineral interactions were observed $(P \geq 0.34)$.

Although starch and NDF digestibility were greater in cows fed the by-product diets, DM and OM digestibilities and TDN were lower compared with cows fed the forage diets (Table 5). Increased digestibility of the 2 carbohydrate fractions was not enough to compensate for the substantial replacement of starch (approxi-

Table 6. Long-chain fatty acid (\% of total fatty acid) composition of diets and ingredients

\begin{tabular}{|c|c|c|c|c|c|c|}
\hline Fatty acid & \multicolumn{2}{|c|}{$\operatorname{Diet}^{1}$} & $\begin{array}{l}\text { Corn } \\
\text { silage }\end{array}$ & $\begin{array}{l}\text { Alfalfa } \\
\text { silage }\end{array}$ & $\begin{array}{c}\text { Forage } \\
\text { concentrate }\end{array}$ & $\begin{array}{l}\text { By-product } \\
\text { concentrate }\end{array}$ \\
\hline $12: 0$ & 1.21 & 1.16 & 2.35 & 0.86 & NA & 0.86 \\
\hline $14: 1$ & 0.92 & 1.56 & 0.86 & 1.73 & 0.54 & 1.73 \\
\hline $16: 0$ & 15.31 & 16.12 & 14.41 & 16.55 & 15.72 & 16.55 \\
\hline $16: 1$ & 0.59 & 0.70 & 0.37 & 0.78 & 0.75 & 0.78 \\
\hline $18: 2$ & 41.55 & 39.29 & 39.75 & 39.17 & 45.06 & 39.17 \\
\hline $20: 0$ & 0.45 & 0.36 & 0.60 & 0.30 & 0.37 & 0.30 \\
\hline $18: 3$ & 4.24 & 4.75 & 4.64 & 4.78 & 3.46 & 4.78 \\
\hline $22: 0$ & 0.23 & 0.10 & 0.40 & 0.03 & 0.15 & 0.03 \\
\hline Other & 11.50 & 9.21 & 18.82 & 6.80 & 4.89 & 6.80 \\
\hline Unsaturated & 73.51 & 74.58 & 70.24 & 75.66 & 76.30 & 75.66 \\
\hline Saturated & 20.76 & 21.83 & 20.23 & 22.23 & 20.60 & 22.23 \\
\hline
\end{tabular}

\footnotetext{
${ }^{1}$ Forage- or by-product-based diets with $\mathrm{Cu}, \mathrm{Zn}$, and $\mathrm{Mn}$ from sulfate or hydroxy mineral sources.
} 
mately $97 \%$ digestible) with NDF (approximately $47 \%$ digestible) in the forage diet.

Cows fed hydroxy minerals had greater NDF digestibility $(P=0.02)$ compared with sulfate sources. Rumen microorganisms require trace minerals; however, feeding recommended concentrations (NRC, 2001) of minerals, particularly $\mathrm{Cu}$, to cows can inhibit rumen microorganisms (Durand and Kawashima, 1980). Excessive $\mathrm{Zn}$ supplementation $(\geq 400 \mathrm{mg} / \mathrm{kg}$ of diet $\mathrm{DM})$ decreased in situ DM digestibility (Arelovich et al., 2000, 2008) and in vitro cellulose digestion (Bonhomme et al., 1979; Eryavuz and Dehority, 2009). Similar observations have been documented regarding excessive $\mathrm{Cu}$ $(\geq 100 \mathrm{mg} / \mathrm{kg}$ ) supplementation (reviewed by Durand and Kawashima, 1980). However, even at biologically relevant concentrations of $\mathrm{Cu}(1 \mathrm{mg} \mathrm{Cu} / \mathrm{L}$ of medium), $\mathrm{Cu}$ sulfate addition decreased in vitro cellulose digestion (Martinez and Church, 1970). Addition of $\mathrm{Cu}$ sulfate to continuous culture reduced methane emissions and increased propionate, likely through defaunation in one experiment (Durand and Kawashima, 1980) but not in another (Slyter and Wolin, 1967). Although, the majority of observations suggest excessive supplemental trace minerals (specifically $\mathrm{Cu}$ and $\mathrm{Zn}$ ) can negatively affect rumen microorganisms and nutrient digestion, omission of trace minerals, specifically $\mathrm{Zn}$, can decrease protozoal growth in pure cultures (Hino et al., 1973). Organic trace mineral supplementation increased total VFA production $4 \mathrm{~h}$ postfeeding compared with sulfate sources in dairy heifers, but no effects on nutrient digestion were observed (Pino and Heinrichs, 2016). Those authors attributed the VFA response to increased utilization of organic trace minerals by rumen microbes. However, dietary concentrations and intakes of $\mathrm{Cu}$ were about 20\% higher for heifers fed the sulfate treatments, which may have contributed to the treatment effect.

Hydroxy $\mathrm{Cu}$ and $\mathrm{Mn}$ are less soluble in rumen fluid than sulfate sources, whereas hydroxy Zn was more soluble than its sulfate counterpart (Genther and Hansen, 2015). Increased NDF digestibility by cows fed hydroxy minerals in the current study could be caused by reduced concentrations of soluble $\mathrm{Cu}$, thereby reducing inhibitory effects on ruminal bacteria. Another possible reason for increased NDF digestibility is that increased soluble Zn stimulated microbial function and subsequent NDF digestion, but inconsistent differences in solubility of Zn between hydroxy and sulfate sources have been reported (Cao et al., 2000; Genther and Hansen, 2015).

\section{Nitrogen Metabolism}

Mineral and the fiber by mineral interaction did not affect $\mathrm{N}$ metabolism $(P>0.34)$, but cows fed the forage diets secreted more $\mathrm{N}$ in milk and urine and retained less $\mathrm{N}(P<0.05)$ than did cows fed the by-product diets (Table 5). Cows consuming forage diets excreted more $\mathrm{N}$ in urine in terms of both mass and as a percentage of $\mathrm{N}$ digested (Table 5). These observations are in agreement with predicted urinary $\mathrm{N}$ excretion (255 and 180 $\mathrm{g} / \mathrm{d}$ ) based on MUN (Kauffman and St-Pierre, 2001) for the forage and by-product diets. Treatment effects on urinary loss of $\mathrm{N}$ could be caused by differences in protein nutrition (e.g., AA profile or degradability) or differences in carbohydrate nutrition. Less urine $\mathrm{N}$ excretion for cows fed the by-product diets compared with forage diets could have been caused by increased hindgut fermentation of the by-product diet. That would increase colonic ammonia absorption and fecal $\mathrm{N}$ (228 vs. $210 \mathrm{~g} / \mathrm{d}$ ), and reduce urinary $\mathrm{N}$ and MUN ( $P$ $<0.01)$ for the by-product diet compared with the forage diet (Olsman et al., 2004). Less urine N and MUN for cows consuming by-product compared with forage diets could also suggest a more efficient capture of ammonia $\mathrm{N}$ and better AA balance. Ruminal microorganism fermentation of soluble sugars and pectins make greater contributions to microbial protein synthesis per unit of carbohydrate fermented than other less rapidly fermentable fiber fractions (Russell et al., 1992).

Apparent retention of $\mathrm{N}$ was greater $(P<0.01)$ for cows fed the by-product diets (Table 5 ), but it was also greater than what is biologically reasonable. Nitrogen retention is typically overestimated using $\mathrm{N}$ balance studies for a variety of methodological reasons (Spanghero and Kowalski, 1997), but these factors should have affected both treatments similarly. Part of the treatment may reflect differences in true retention of $\mathrm{N}$ caused by differences in energy partitioning or other factors.

\section{Milk FA Profile}

Milk FA profile was examined because it can reflect changes in ruminal fermentation (Fievez et al., 2012), and $\mathrm{Cu}$ nutrition can affect FA metabolism (Engle, 2011). Cows fed the by-product diet had greater $(P<$ 0.05 ) concentrations of UFA and PUFA, lower concentrations of 16:0 $(P<0.02)$, and had decreased concentrations of many, but not all, odd- and branched-chain FA compared with the forage diets (Table 7). Concentrations of trans-10,cis-12 CLA concentrations tended to be greater $(P<0.07)$ for the by-product compared with the forage diet (Table 7), which supports the lower $(P=0.03)$ milk fat yields by those cows (Table $4)$. Cows fed sulfate minerals tended to have greater concentrations of many odd- and branched-chain FA (Table 7), but the main effect of mineral source did not affect other FA. Interactions between mineral and fiber 
were observed for many of the aggregated FA fractions (e.g., saturated and unsaturated) and for 16:0. Feeding sulfate minerals with forage diets tended to increase 16:0 and SFA, but concentrations decreased when sulfate minerals were fed with by-product diets. The opposite was observed for UFA and MUFA. Dietary $\mathrm{Cu}$ likely affects ruminal biohydrogenation (Engle, 2011); however, effects on specific milk FA have been inconsistent (Morales et al., 2000; Engle et al., 2001). The interaction between fiber and trace minerals on milk FA suggests that source and type of carbohydrates may be one reason for different responses across studies.

Milk FA profile reflects the interaction of diet, microbial population and fermentation, and mammary gland metabolism (Bauman and Griinari, 2003). Forage source and mineral source can alter rumen microbial activity and fermentation end-products. Ruminal microbial effects on milk FA in response to different dietary forage sources or forage-to-concentrate ratio are predominantly reflected by changes in odd- and branched-chain milk FA profiles (Vlaeminck et al., 2006). Rumen cellulolytic bacteria primarily increase concentrations of even and odd-iso FA, whereas amyloytic bacteria increase odd-chain and anteiso branched-chain FA (Fievez et al., 2012). Increased concentrations of iso-15:0 and iso17:0 in milk FA for cows consuming the by-product diet compared with the forage diet (Table 7) may have been because cellulolytic bacteria increased in response

Table 7. Effects of feeding different fiber and trace mineral sources on milk fatty acids $(\mathrm{g} / \mathrm{kg})$

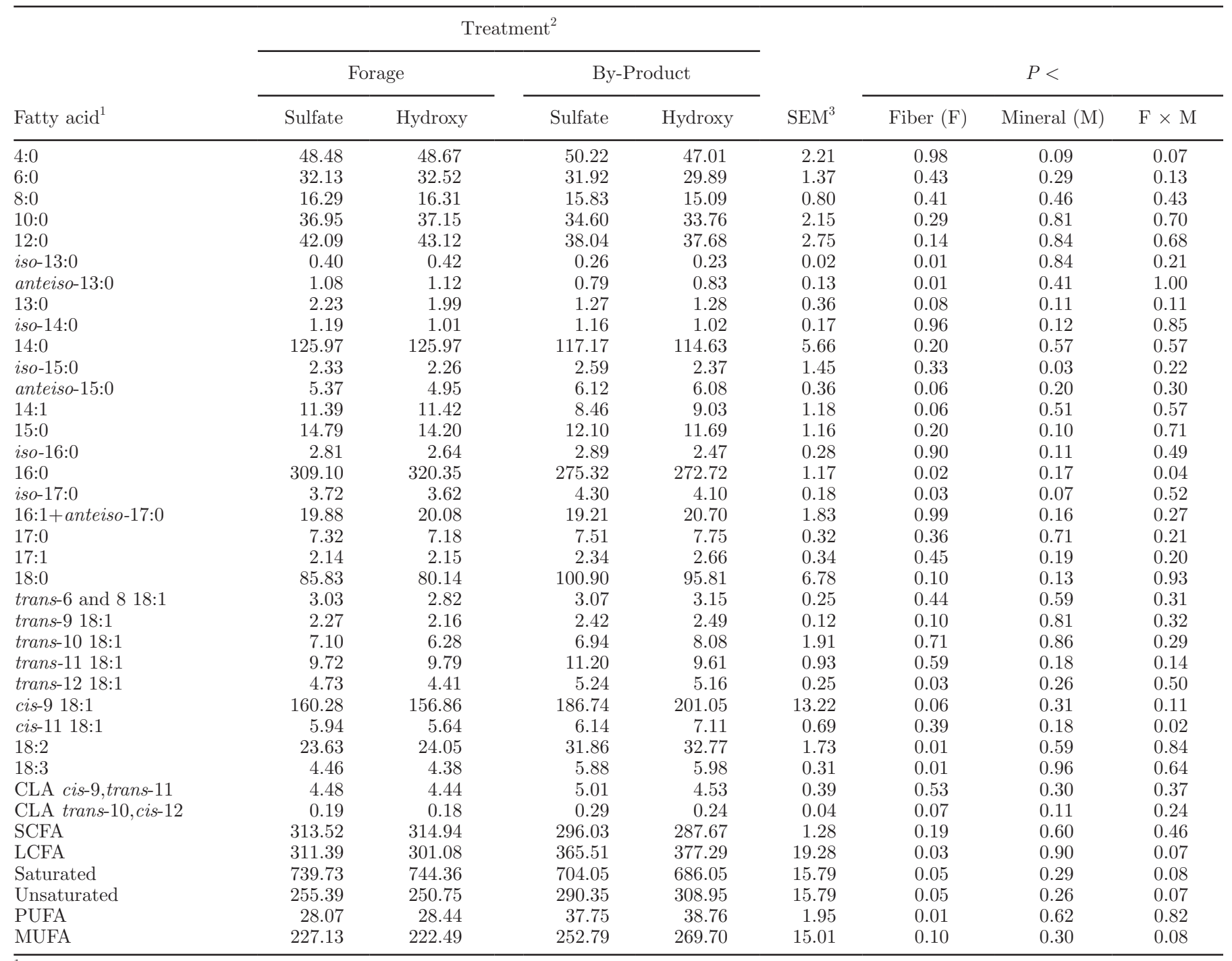

${ }^{1}$ Number of carbons:number of double bonds. SCFA = short-chain fatty acids; LCFA = long-chain fatty acids.

${ }^{2}$ Forage- or by-product-based diets with $\mathrm{Cu}, \mathrm{Zn}$, and $\mathrm{Mn}$ from sulfate or hydroxy mineral sources.

${ }^{3}$ Data were unbalanced due to one missing observation; therefore, the greatest SEM values were reported. 
to increased dietary NDF concentrations (Table 2). Anteiso-15:0 may have increased in cows fed the byproduct diet because of fermentation of pectin and sugars (Vlaeminck et al., 2006). Whereas, increased concentrations of PUFA, LCFA, 18:2, and 18:3 for the by-product diet compared with the control may have been due to the increased supply of digestible LCFA (Table 5).

\section{CONCLUSIONS}

Feeding high concentrations of by-products to midto late-lactation dairy cows did not affect DMI, but reduced the concentration and intake of TDN. Fiber digestibility and milk FA profiles differed when animals were fed hydroxy or sulfate trace mineral sources. Increased NDF digestion when hydroxy minerals were fed could suggest that hydroxy mineral supplementation is beneficial for cellulolytic bacteria; however, a more likely explanation is that sulfate trace minerals are inhibitory to fiber-digesting microbes. The increase in NDF digestibility with hydroxy minerals was not great enough to increase TDN concentration of the total diet.

\section{ACKNOWLEDGMENTS}

This study was partially funded by Micronutrients USA LLC (Indianapolis, IN). Thanks are extended to MaryBeth Hall and Jan Pitas (USDA Dairy Forage Research Center, Madison, WI) for conducting the soluble fiber assays.

\section{REFERENCES}

Allen, M. S., and A. R. Mertens. 1988. Evaluating constraints on fiber digestion by rumen microbes. J. Nutr. 118:261-270.

AOAC International. 2000. Official Methods of Analysis. Vol. 1 and 2. 17 ed. AOAC International, Gaithersburg, MD.

Arelovich, H. M., H. E. Laborde, M. I. Amela, M. B. Torrea, and M. F. Martínez. 2008. Effects of dietary addition of zinc and(or) monensin on performance, rumen fermentation and digesta kinetics in beef cattle. Span. J. Agric. Res. 6:11.

Arelovich, H. M., F. N. Owens, G. W. Horn, and J. A. Vizcarra. 2000. Effects of supplemental zinc and manganese on ruminal fermentation, forage intake, and digestion by cattle fed prairie hay and urea. J. Anim. Sci. 78:2972-2979.

Bauman, D. E., and J. M. Griinari. 2003. Nutritional regulation of milk fat synthesis. Annu. Rev. Nutr. 23:203-227.

Bhatti, S. A., and J. L. Firkins. 1995. Kinetics of hydration and functional specific gravity of fibrous feed by-products. J. Anim. Sci. 73:1449-1458

Bonhomme, A., M. Durand, C. Dumay, and P. Beaumatin. 1979 Etude in vitro du comportement des populations microbiennes du rumen en présence de zinc sous forme de sulfate. Ann. Biol. Anim. Biochim. Biophys. 19:937-942.

Cao, J., P. R. Henry, C. B. Ammerman, R. D. Miles, and R. C. Littell. 2000. Relative bioavailability of basic zinc sulfate and basic zinc chloride for chicks. J. Appl. Poult. Res. 9:513-517.
CVAS (Cumberland Valley Analytical Services). 2014. Resource-lab procedures. Accessed Sep. 10, 2015. http://www.Foragelab.com/ Resources/Lab-Procedures.

Durand, M., and R. Kawashima. 1980. Influence of minerals in rumen microbial digestion. Pages 375-408 in Digestive Physiology and Metabolism in Ruminants: Proc. 5th Internat. Symp. Rumin. Physio. Y. Ruckebusch and P. Thivend, ed. Springer Netherlands, Dordrecht, the Netherlands.

Engle, T. E. 2011. Copper and lipid metabolism in beef cattle: A review. J. Anim. Sci. 89:591-596.

Engle, T. E., V. Fellner, and J. W. Spears. 2001. Copper status, serum cholesterol, and milk fatty acid profile in Holstein cows fed varying concentrations of copper. J. Dairy Sci. 84:2308-2313.

Eryavuz, A., and B. A. Dehority. 2009. Effects of supplemental zinc concentration on cellulose digestion and cellulolytic and total bacterial numbers in vitro. Anim. Feed Sci. Technol. 151:175-183.

Faulkner, M. J., N. R. St-Pierre, and W. P. Weiss. 2017. Effect of source of trace minerals in either forage- or by-product-based diets fed to dairy cows: 2. Apparent absorption and retention of minerals. J. Dairy Sci. 100:5368-5377. https://doi.org/10.3168/ jds.2016-12096.

Ferraretto, L. F., P. M. Crump, and R. D. Shaver. 2013. Effect of cereal grain type and corn grain harvesting and processing methods on intake, digestion, and milk production by dairy cows through a meta-analysis. J. Dairy Sci. 96:533-550.

Fievez, V., E. Colman, J. M. Castro-Montoya, I. Stefanov, and B. Vlaeminck. 2012. Milk odd- and branched-chain fatty acids as biomarkers of rumen function-An update. Anim. Feed Sci. Technol. 172:51-65.

Firkins, J. L. 1997. Effects of feeding nonforage fiber sources on site of fiber digestion. J. Dairy Sci. 80:1426-1437.

Genther, O. N., and S. L. Hansen. 2015. The effect of trace mineral source and concentration on ruminal digestion and mineral solubility. J. Dairy Sci. 98:566-573.

Gott, P. N., J. S. Hogan, and W. P. Weiss. 2015. Effects of various starch feeding regimens on responses of dairy cows to intramammary lipopolysaccharide infusion. J. Dairy Sci. 98:1786-1796.

Hall, M. B., W. H. Hoover, J. P. Jennings, and T. K. M. Webster 1999. A method for partitioning neutral detergent-soluble carbohydrates. J. Sci. Food Agric. 79:2079-2086.

Herrera-Saldana, R. E., J. T. Huber, and M. H. Poore. 1990. Dry matter, crude protein, and starch degradability of five cereal grains. J Dairy Sci. 73:2386-2393.

Hino, T., M. Kametaka, and M. Kandatsu. 1973. The cultivation of rumen oligotrich protozoa: III. White clover factors which stimulate the growth of entodinia. J. Gen. Appl. Microbiol. 19:397-413.

Jenkins, T. C. 2000. Feeding oleamide to lactating jersey cows 1. Effects on lactation performance and milk fatty acid composition. J. Dairy Sci. 83:332-337.

Kauffman, A. J., and N. R. St-Pierre. 2001. The relationship of milk urea nitrogen to urine nitrogen excretion in Holstein and Jersey cows. J. Dairy Sci. 84:2284-2294

Krause, K. M., and D. K. Combs. 2003. Effects of forage particle size, forage source, and grain fermentability on performance and ruminal pH in midlactation cows. J. Dairy Sci. 86:1382-1397.

Loor, J. J., K. Ueda, A. Ferlay, Y. Chilliard, and M. Doreau. 2004 Biohydrogenation, duodenal flow, and intestinal digestibility of trans fatty acids and conjugated linoleic acids in response to dietary forage:concentrate ratio and linseed oil in dairy cows. J. Dairy Sci. 87:2472-2485

Martinez, A., and D. C. Church. 1970. Effect of various mineral elements on rumen cellulose digestion. J. Anim. Sci. 31:982-990.

Morales, M. S., D. L. Palmquist, and W. P. Weiss. 2000. Effects of fat source and copper on unsaturation of blood and milk triacylglycerol fatty acids in Holstein and Jersey cows. J. Dairy Sci. 83:2105-2111.

NRC. 2001. Nutrient Requirements of Dairy Cattle. 7th rev. ed. ed Natl. Acad. Sci., Washington, DC.

Olsman, A. F. S., C. M. Huurdeman, W. L. Jansen, J. Haaksma, M. M. S. van Oldruitenborgh-Oosterbaan, and A. C. Beynen. 2004 Macronutrient digestibility, nitrogen balance, plasma indicators of 
protein metabolism and mineral absorption in horses fed a ration rich in sugar beet pulp. J. Anim. Physiol. Anim. Nutr. (Berl.) 88:321-331.

Pino, F., and A. J. Heinrichs. 2016. Effect of trace minerals and starch on digestibility and rumen fermentation in diets for dairy heifers. J. Dairy Sci. 99:2797-2810.

Russell, J. B., J. D. O'connor, P. J. Fox, P. J. Van Soest, and C. J. Sniffen. 1992. A net carbohydrate and protein system for evaluating cattle diets: I. Ruminal fermentation. J. Anim. Sci. 70:35513561.

Slyter, L. L., and M. J. Wolin. 1967. Copper sulfate-induced fermentation changes in continuous cultures of the rumen microbial ecosystem. Appl. Microbiol. 15:1160-1164.

Spanghero, M., and Z. M. Kowalski. 1997. Critical analysis of N balance experiments with lactating dairy cows. Livest. Prod. Sci. $52: 113-122$.

Sutton, J. D., J. A. Bines, S. V. Morant, D. J. Napper, and D. J. Givens. 1987. A comparison of starchy and fibrous concentrates for milk production, energy utilization and hay intake by Friesian cows. J. Agric. Sci. 109:375-386.
Valadares Filho, S. C., G. A. Broderick, R. F. D. Valadares, and M. K. Clayton. 2000. Effect of replacing alfalfa silage with high moisture corn on nutrient utilization and milk production. J. Dairy Sci. 83:106-114.

Varga, G. A., and E. S. Kolver. 1997. Microbial and animal limitations to fiber digestion and utilization. J. Nutr. 127:819S-823S

Vlaeminck, B., V. Fievez, A. R. J. Cabrita, A. J. M. Fonseca, and R. J. Dewhurst. 2006. Factors affecting odd- and branched-chain fatty acids in milk: A review. Anim. Feed Sci. Technol. 131:389-417.

Weiss, W. P., N. R. St-Pierre, and L. B. Willett. 2009. Varying type of forage, concentration of metabolizable protein, and source of carbohydrate affects nutrient digestibility and production by dairy cows. J. Dairy Sci. 92:5595-5606.

Weiss, W. P., and D. J. Wyatt. 2000. Effect of oil content and kernel processing of corn silage on digestibility and milk production by dairy cows. J. Dairy Sci. 83:351-358.

Weiss, W. P., and D. J. Wyatt. 2003. Effect of dietary fat and vitamin $\mathrm{E}$ on $\alpha$-tocopherol in milk from dairy cows. J. Dairy Sci. 86:3582-3591. 